\title{
Detrimental Effects of Life Transitions on Dietary Health
}

\author{
Torben $\mathrm{H}^{*}$ and Thomsen TU \\ Department of Marketing, Denmark
}

ISSN: 2640-9208

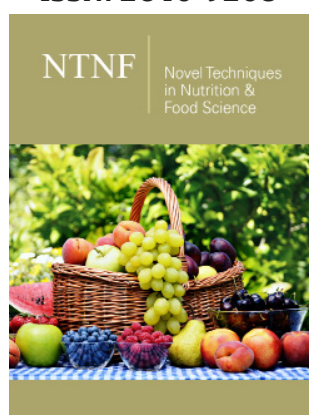

${ }^{* 1}$ Corresponding author: Torben $\mathrm{H}_{,}$ Department of Marketing, Denmark

Submission: 埇 March 15, 2019

Published: 眥 March 21, 2019

Volume 3 - Issue 4

How to cite this article: Torben $\mathrm{H}_{4}$ Thomsen T. Detrimental Effects of Life Transitions on Dietary Health. Nov Tech Nutri Food Sci. 3(4).NTNF.000570.2019. DOI: 10.31031/NTNF.2019.03.000570

Copyright@ Torben H, This article is distributed under the terms of the Creative Commons Attribution 4.0 International License, which permits unrestricted use and redistribution provided that the original author and source are credited.

\section{Introduction}

Past research documents that life transitions trigger changes in lifestyles and consumption patterns [1-3]. This is primarily attributed to changes in consumer identity [4,5], changes in household resources [6] and situational challenges, i.e., stress [7]. Notably, a key area of consumption that changes during life transitions is diet composition [6]. For example, unemployment can trigger a significant increase in the intake of animal-based foods, and consequently fat and protein, and in the longer run increase the intake of carbohydrates and added sugar [8]. Another example shows that getting divorced puts men at a $23 \%$ higher risk of apoplexy than married men, single men (that have never been married), or women. This is partly attributed to their lack of dietary adaptation skills upon divorce [9]. Also, research suggests that living with parents during university studies-rather than having your own bachelor household - can be associated with better eating habits and lower prevalence of overweight and obesity [10].

\section{Life transitions}

Important life passages typically consist of three phases, that is:

A. Separation, in which people disengage from the current status,

B. liminality, in which people encounter ambiguity and unanchored identity

C. incorporation, in which people integrate the self with the new circumstances $[11,12]$.

Traditional life cycle models cover a multitude of life transitions, i.e., transitioning to be bachelors, young couples without children, full nest couples, empty nest couples, and possibly solitary survivors [1-3]. Since the 1970'ies, additional family statuses of being continuously childless and divorced have been added to the life cycle models due to changing demographics [2], and more recently, never married singles and single parent child-births have prompted the renaming of family life cycle models into household life cycle models $[13,14]$.

\section{Dietary implications and solutions}

While some life transitions with detrimental dietary implications are hard to predict (i.e., unemployment), other life transitions are experienced by a large part of a population. These transitions are in particular: Moving away from home to enter bachelorhood, becoming divorcees, and turning into solitary survivors due to the death of the partner, respectively. Also, these transitions all potentially lead to single lifestyles, which on average include an unhealthier diet than is the case for married couples, especially as far as single males are concerned [15]. At the same time, single household consumption of certain goods varies considerably in different life stages [14], and it is therefore likely that segments in life transitions must be viewed separately and not just be compared with non-single households. To maximize chances of success, practical dietary support and guidance offered to these segments should contribute to consumer contemplation, preparation, action and/or maintenance of new habits [16]. Contemplation is often supported through informational approaches, for example information about nutritional labelling and dietary recommendations-i.e., how to use keyhole labels promoted by the Danish Veterinary and Food Administration [17]. 
Preparation can be amplified through exchange and social support; for example, through social media interaction- i.e., the food hero multichannel social marketing campaign [18]. Action requires appropriate resources which can be provided in terms of skills, in terms of motivating to prioritize time or to develop time-efficient dietary habits, or in terms of provisioning an affordable diet (e.g., starter kits with kitchen utensil for single meal production, cooking classes, or social eating arrangements). Finally, maintenance can be supported by revisiting and optimizing all of the above, including social feedback on performance. Consequently, in order to offer segments useful practical help, all of the above-mentioned approaches should be considered.

\section{References}

1. Gilly MC, Enis BM (1982) Recycling the family life cycle: a proposal for redefinition. In: Andrew AM, Arbor MIA (Eds.), Advances in Consumer Research, Association for Consumer Research 9: 271-276.

2. Murphy PE, Staples WA (1979) A modernized family life cycle. Journal of consumer research 6(1): 12-22.

3. Wells WD, Gubar G (1966) Life cycle concept in marketing research. Journal of Marketing Research pp. 355-363.

4. Schouten JW (1991) Selves in transition: Symbolic consumption in personal rites of passage and identity reconstruction. Journal of consumer research 17(4): 412-425.

5. Barnhart M, Peñaloza L (2012) Who are you calling old? Negotiating old age identity in the elderly consumption ensemble. Journal of Consumer Research 39(6): 1133-1153.

6. Schaninger CM, Danko WD (1993) A conceptual and empirical comparison of alternative household life cycle models. Journal of Consumer Research 19(4): 580-594.
7. Andreasen, Alan R (1984) Life status changes and changes in consumer preferences and satisfaction. Journal of Consumer Research 11(3): 784794.

8. Smed S, Tetens I, Lund TB, Holm L, Nielsen AL (2018) The consequences of unemployment on diet composition and purchase behavior: a longitudinal study from Denmark. Public Health Nutr 21(3): 580-592.

9. Andersen KK, Olsen TS (2018) Married, unmarried, divorced, and widowed and the risk of stroke. Acta Neurologica Scandinavica 138(1): 41-46.

10. Schnettler B, Denegri M, Miranda H, Sepúlveda J, Orellana L, et al. (2013) Eating habits and subjective well-being among university students in southern Chile. Nutr Hosp 28(6): 2221-2228.

11. Turner VW (1969) The ritual process: structure and anti-structure. Chicago: Aldine.

12. Arnold GV, Vizedom MB, CaffeeGL (1960) The Rites of Passage, trans. Chicago: University of Chicago Press, p. 198.

13. James FE, Blackwell DR, Miniard PW (1993) Consumer Behavior. Dryden, New York, USA.

14. Wilkes RE (1995) Household life-cycle stages, transitions, and product expenditures. Journal of Consumer Research 22(1): 27-42.

15. Health (2017) The Danes' Health-The National Health Profile 2017. Copenhagen: The National Board of Health.

16. https://www.niddk.nih.gov/health-information/diet-nutrition/ changing-habits-better-health

17. https://altomkost.dk/noeglehullet/kampagner/\#c49582

18. Tobey LN, Manore MM (2014) Social media and nutrition education: the food hero experience. J Nutr Educ Behav 46(2): 128-133. 